\title{
Rhyparida foaensis (Jolivet, Verma \& Mille, 2007), comb. n. (Coleoptera, Chrysomelidae) and implications for the colonization of New Caledonia
}

\author{
Jesús Gómez-Zurita' \\ I Institut de Biologia Evolutiva (CSIC-UPF), Natural Resources-CSIC, Pg. Maritim de la Barceloneta 37, \\ 08003 Barcelona, Spain \\ Corresponding author: Jesús Gómez-Zurita (j.gomez-zurita@ibe.upf-csic.es) \\ Academic editor: Michael Schmitt | Received 30 March 2011 | Accepted 8 June 2011 | Published 21 December 2011 \\ Citation: Gómez-Zurita J (2011) Rhyparida foaensis (Jolivet, Verma \& Mille, 2007), comb. n. (Coleoptera, Chrysomelidae) \\ and implications for the colonization of New Caledonia. In: Jolivet P, Santiago-Blay J, Schmitt M (Eds) Research on \\ Chrysomelidae 3. ZooKeys 157: 33-44. doi: 10.3897/zookeys.157.1320
}

\begin{abstract}
The study of external morphology of the New Caledonian leaf beetle Dematochroma foaensis Jolivet, Verma \& Mille (Chrysomelidae, Eumolpinae, Colaspoidini) substantiates its new combination into the genus Rhyparida Baly (Chrysomelidae, Eumolpinae, Nodinini). The species is redescribed here to highlight characters important for suprageneric diagnosis. This is the second species of Nodinini found in New Caledonia, otherwise rich in species of Colaspoidini, raising questions about the paucity of Rhyparida and this tribe in New Caledonian fauna, when they are dominant in surrounding archipelagoes, and very rich in potential source areas such as Australia and New Guinea. Some alternative explanations for this pattern are advanced, serving as alternative hypotheses until our knowledge on the ecology of these species improves or supported phylogenetic scenarios become available for this group.
\end{abstract}

\section{Keywords}

Rhyparida, Dematochroma, New Caledonia, island disharmony, new combination

\section{Introduction}

Generic attributions of New Caledonian Eumolpinae are currently in need of revision. Montrouzier (1861) and Fauvel (1862) described two medium sized species of Eumolpinae from the archipelago as Edusa laboulbenei Montrouzier and Chalcoplacis antipodum Fauvel, respectively. Chapuis (1874) described another New Caledo-

Copyright Jesús Gómez-Zurita. This is an open access article distributed under the terms of the Creative Commons Attribution License 3.0 (CC-BY), which permits unrestricted use, distribution, and reproduction in any medium, provided the original author and source are credited. 
nian species within his "Colaspitae" and under a new genus, Thasycles cordiformis Chapuis, which was later synonymised with Montrouzier's taxon (Lefèvre 1876). Finally, Lefèvre (1885) ranked the two recognized New Caledonian taxa into the genus Dematochroma Baly, characterized by the species D. picea Baly, 1864, an endemic eumolpine from Lord Howe island in the so-called Lord Howe Rise, a marine ridge separated from the Norfolk Ridge, the oceanic feature where New Caledonia belongs to (Keast 1996). The three species have markedly divergent external appearance, perhaps as much as to be treated as different genera (Fig. 1). Heller (1916) acknowledged the differences between the forms from New Caledonia and Lord Howe, highlighting the insufficient justification by Lefèvre (1885) to place them together, and preferred to treat them in different genera-against the choice of Clavareau (1914)_maintaining Chapuis' name Thasycles for the Neocaledonian taxa. In fact, he described under Thasycles six new species of Eumolpinae, again markedly divergent among each other and from either previously described taxon (see also GómezZurita in press). In the absence of explicit diagnostic characters, his decision to rank species so different under the same generic name was mostly based on the relatively large size of these species and perhaps the prejudice of a fauna evolved in isolation from one or at most few ancestors. In the same tradition, Pierre Jolivet and his coauthors (Jolivet et al. 2007a,b,c, 2009) described many New Caledonian eumolpine beetles, recovering the generic name Dematochroma, whereby the distinguishing feature to place the new species under this genus is mainly their moderate size $(5-9 \mathrm{~mm}$ long; Jolivet et al. 2007b).

Size as a systematic criterion is liable to taxonomic confusion. In my initial steps to understand the systematic structure of New Caledonian Eumolpinae above the species level, both using morphological and DNA-based criteria, stood out one example in need of additional study. The $6 \mathrm{~mm}$ long species described as Dematochroma foaensis Jolivet, Verma \& Mille, 2007a: 43 belongs into a distantly related suprageneric rank compared to Dematochroma or most other New Caledonian Eumolpinae. Indeed, after Stethotes bertiae Jolivet, Verma \& Mille, 2007b: 81 it is the second representative reported from this archipelago as belonging into the tribe Nodinini, as opposed to Colaspoidini, where Dematochroma and most other New Caledonian species appear to belong. The species shows highly divergent characters as compared to Dematochroma sensu auctorum or any other Eumolpinae in New Caledonia. These include the lack of dorsal longitudinal groove on pygidium, meso- and metatibiae with preapical emargination, and bifid claws. A closer analysis of morphology of several specimens showed it to present the characters considered by previous authors to diagnose the genus Rhyparida Baly, 1861 (e.g., Gressitt 1969). Thus, herein, I propose the name Rhyparida foaensis (Jolivet, Verma \& Mille), comb. n. The original diagnosis for the species was succinct and lacked mention to those systematic characters important for the recognition of the species and its correct placement in the system of Eumolpinae. Thus, a redescription is provided below, with illustrations of male and female genitalia for the first time, as well as a discussion about the presence of this isolated Nodinini in New Caledonia. 


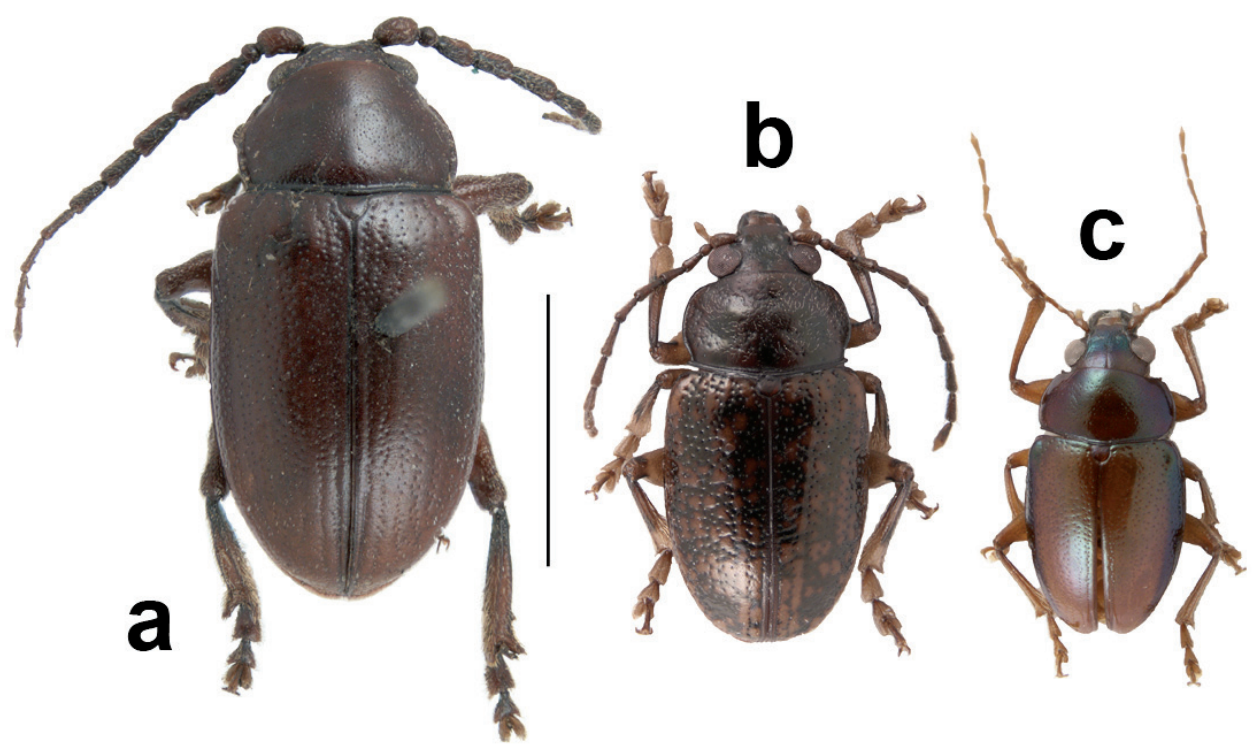

Figure I. Habitus of three species of Dematochroma a Male holotype of D. piceum Baly from Lord Howe Island (N.H.M., London) b male of D. laboulbenei (Montrouzier) from Thio, New Caledonia (voucher no. IBE-JGZ-NC-0112; I.B.E., Barcelona), and c male of D. antipodum (Fauvel) from L'Aoupinié, New Caledonia (voucher no. IBE-JGZ-NC-0144; I.B.E., Barcelona). Scale bar $=5 \mathrm{~mm}$.

\section{Taxonomy}

\section{Redescription of Rhyparida foaensis (Jolivet, Verma \& Mille)}

\section{Rhyparida foaensis (Jolivet, Verma \& Mille)}

http://species-id.net/wiki/Rhyparida_foaensis

Material examined. Type material: (1) Holotype, one male, La Foa, $21^{\circ} 44 \mathrm{~S}, 165^{\circ} 54 \mathrm{E}$, 10 February 2004, M’bouéri R. M. leg. (Museum National d'Histoire Naturelle, Paris); (2) Paratype, one female, Ouégoa, Mandjélia, $20.39683^{\circ} \mathrm{S}, 164.53218^{\circ} \mathrm{E}, 787 \mathrm{~m}$, 7-8 February 2005, S. Cazères \& C. Mille leg. (Museum National d'Histoire Naturelle, Paris). Other material: (3) two females, Caavatch (=Kaavac), 5 February 1977, Dr. J. Balogh leg. (Hungarian Natural History Museum, Budapest); (5) three females, Province Sud, Camp Brun, 14 March 1994, on Melaleuca quinquenervia, M. Schöller leg. (M. Schöller coll., Berlin); (4) one female, Province Nord, Hienghene 20.69545으, 164.94274 $\mathrm{E} 24 \mathrm{~m}, 8$ April 2008, J. Gómez-Zurita leg. (J. Gómez-Zurita coll., voucher no. NC-0110, Institute of Evolutionary Biology, Barcelona).

Description. Habitus (Fig. 2). Body stout, elongated oval (6.1 mm long, $3.4 \mathrm{~mm}$ wide), moderately convex. Ground color orange testaceous, with infuscate head sutures, inverted triangle on frons, apical antennal segments, margins and discal markings on pronotum, scutellum, elytral suture, humeri, medially for short distance on 


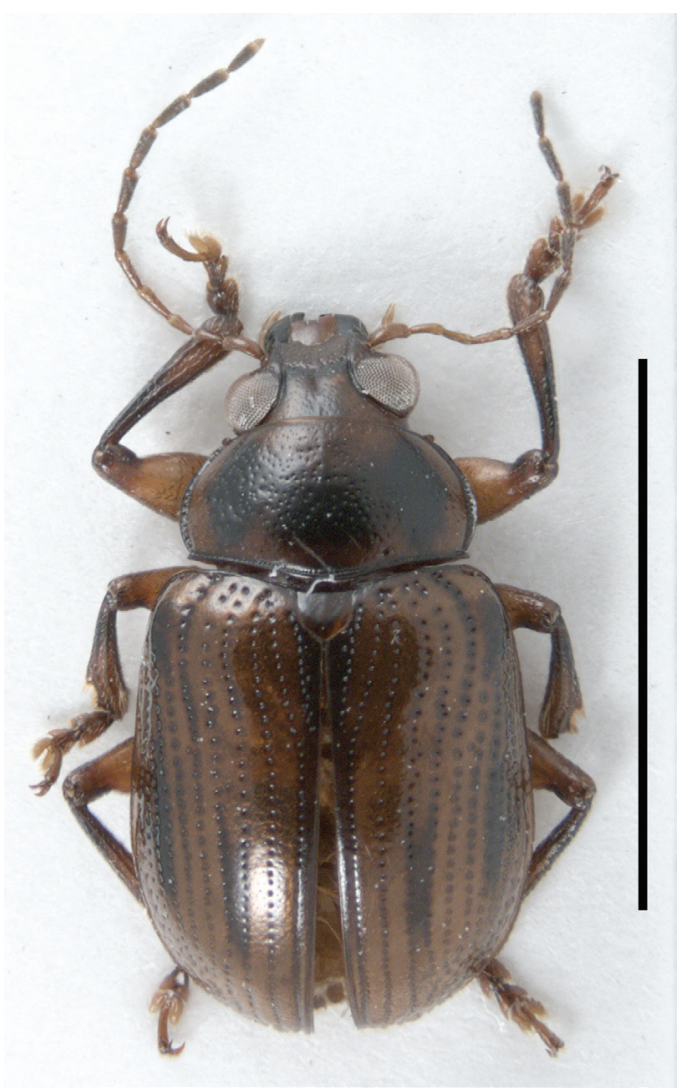

Figure 2. Habitus of Rhyparida foaensis (Jolivet, Verma \& Mille). Scale bar $=5 \mathrm{~mm}$.

third and seventh elytral intervals, apex of femora, basal half of tibiae, episterna and ventral thoracic segments; mandibles black.

Head large, deeply inserted into pronotum, nearly to upper eye margin; surface very delicately microreticulated; vertex weakly convex, very finely, rather densely and homogeneously punctured, with very fine median longitudinal impression, becoming progressively larger, on depressed longitudinal area on frons, joined apically to transversally widely obtuse fronto-clypeal suture. Clypeus wider than long, subtrapezoidal, depressed apically, with deep median semicircular apical emargination, flanked laterally by shortly produced denticles; surface microreticulated, with larger, deeper punctures than those on vertex, bearing minute, very fine setae anteriorly. Labrum as long as wide; surface finely microreticulated; sides feebly convergent towards round anterior angles; apex depressed and weakly emarginated; anterior angles with one pair of nearly adjacent fine golden setae; two setae anteriorly on disc. Genae very short, with some fine setae below eye margin. Eyes very big, dorsoventrally elongated; deeply emarginated at inner border for antennal insertion; supraocular margin furrowed, furrow not surpassing eye margin above, with long, yellowish dorsal seta. Space for antennal insertion concave, slightly raised dorsally above clypeus level; microreticulated, unpunc- 
tured, with one anterior, oblique fine golden seta. Antennae long and slender, reaching basal third of elytra; scape long, weakly flattened and arched antero-posteriorly; second antennomere elongated, slightly clavate, weakly curved, 0.66x as long as first; third segment straight, as long as second; antennomeres 4-5 subcylindrical, slightly shorter than scape, narrow and slender; 6-10 as long as scape, slightly widened towards apex, densely setose; apical antennomere longest, sharply pointed and paler at apex. Maxillary palpi short, slender; apical palpomere elongated, subconical.

Pronotum transverse, $0.58 \times$ as long as wide between posterior angles, shorter than head, transversally convex, especially at anterior angles; posterior border weakly bisinuated with weakly projecting median lobe, finely margined with premarginal line of dense dot-like impressions; posterior angles laterally projecting as small teeth continuing basal margin, with large apical setigerous pore; anterior border nearly straight, finely margined at sides, with margin broader and more imprecisely defined at middle; anterior angles laterally and slightly obliquely projecting as small teeth with large setigerous pore at apex; sides broadly curved, wider behind middle; lateral margins relatively wide, flat, glossy, with internal row of dense round impressions; pronotal surface delicately microreticulated, rather uniformly and densely covered by shallow, moderate punctures, smaller, almost disappearing near borders. Anterior border of hypomeron more or less straight, regularly continuing profile of anterior border of pronotum with that of prosternum, both remaining largely separated by anterior margin of hypomeron (see Fig. 4f in Gressitt 1967); hypomera finely alutaceous, unpunctured, with shallow, wavy longitudinal impressions on disc; posterior border of hypomera surrounding procoxae posteriorly for $2 / 3$ of their width, joining apex of prosternal process laterally, enclosing procoxal cavities behind. Prosternum narrow, slightly convex before coxae; anterior border with slightly raised broad margin and weakly emarginated medially; very finely alutaceous, with scattered, fine long yellowish setae; prosternal process broad, as wide as base of femora between coxae, progressively widening apically, following contour of coxae to join posterior border of hypomera; apex of prosternal process straight, twice as wide as width between coxae. Procoxae ovoid, slightly transverse. Combined mesanepisternum and mesepimeron subtrapezoidal, transverse, finely alutaceous, unpunctured. Mesoventrite relatively long, glossy, unpunctured; process long, spatula-like, apex convex, glossy, with few scattered very fine yellowish setae. Metanepisterna long, finely microreticulated, with scattered minute punctures and very fine, short recumbent whitish setae. Metaventrite as long as first abdominal ventrite; disc below level of mesosternal process, glossy, nearly unpunctured; sides finely alutaceous, with scattered minute punctures and very fine, short whitish setae; posterior border with short median notch.

Scutellum as long as broad at base, sides straight, weakly divergent at basal 2/3, curved at obtuse angle to obtusely pointed apex; surface finely alutaceous, unpunctured. Elytra slightly broader than base of pronotum; humeri round, slightly callose; sides very feebly curved, with maximum width behind middle, and regularly curved to broadly round apex; margins feebly explanate, entirely visible from above; surface shiny, with dense unordered minute punctures and regular series of strong punctures 
separated at most by distance equal to their diameter; short scutellar striae of some 14 punctures starting before middle of scutellum and obliquely directed to suture; sutural striae reaching from base of elytra to sutural angles, joining marginal striae at inner edge of explanate margin of elytra; four longitudinal discal striae from base of elytra joining successively to apical ends of ninth, eighth, seventh and sixth striae on preapical declivity of elytra; basal ends of striae 6-8 behind humeri and of premarginal stria 9 behind middle of elytra; short premarginal posthumeral striae, curved and convergent with elytral margin before middle of elytra; space between striae 7 and 8, medially and at lateral declivity of elytra occupied by two additional shorter longitudinal striae convergent at both ends; darkened sutural interval, humeri, elongated spots medially on disc on third interval and more advanced at lateral declivity of elytra on seventh interval between stria 7 and internal row of additional posthumeral striae. Epipleura flat, unpunctured, shiny, broad basally and gradually narrowing toward apex; only visible laterally below humeri. Species fully winged.

Profemora spindle-shaped at basal 3/4, nearly cylindrical at apical quarter; extremely finely alutaceous with scattered minute punctures and very short appressed setae on basal 3/4 and coarser punctures and longer setae at apical 1/4. Protibiae very slightly curved inward, gradually widened toward apex; with several fine longitudinal ridges and longitudinal series of semierect golden setae at intervals; apex concave, obliquely cut for tarsal insertion, densely setose internally. Protarsi $0.6 \times$ as long as protibiae; first tarsomere slightly expanded laterally, longer than wide at concave apex; second shorter than first, triangular with broadly concave apex; third deeply and narrowly bilobed; fifth longer than tarsomeres $2-3$, slender, subparallel, ventrally curved; claws bifid, weakly divergent, long, sharp, with short, sharp inner teeth. Median and hind legs very similar to anterior legs, but tibiae straight, with conspicuous preapical emargination externally, margined by fringe of erect golden setae and apex not densely setose internally. Abdominal ventrites finely microsculptured, shiny, narrow, strongly transverse, with posterior border increasing concavity from ventrites one to four, finely but more or less uniformly punctured and with very fine, short whitish setae; sides corrugated; anterior process between metacoxae of first abdominal ventrite broader than long, regularly curved; last abdominal ventrite very feebly emarginated.

Median lobe of the aedeagus (Fig. 3a,b) strongly bent at right angle near base, dorso-ventrally flattened and nearly straight at apical $2 / 3$; sides slightly divergent, reaching maximum width at mid-level of ostium, feebly converging before abruptly tapering at obtuse angle before apex; apex anteriorly prolonged as blunt median triangular denticle curved dorsally; median dorsal flap broad, spatula-like, with short narrow base $0.5 \times$ as wide as broadest point medially, before regularly curved nearly semicircular apex. Spermatheca (Fig. 3c,d) U-shaped with pump slightly shorter than receptacle, gradually narrowing towards curved pointed apex; proximal end slightly broadened before narrow elongated basal appendix attached prebasally to very fine, transparent spermathecal duct; spermathecal gland apparently attached to spermathecal duct distally from spermatheca at $1.5 \times$ its length. 


\section{Diversity and distribution of Rhyparida}

As it occurs with most Eumolpinae genera, the objective limits of Rhyparida need to be revised and it is possible that profound changes will affect the systematics of the group (C.A.M. Reid, Australian Museum, pers. comm.). However, before this revision is attempted, following the latest treatments of the genus by several specialists, it is possible to draw some preliminary conclusions about the diversity and biogeography of the genus. Clavareau's (1914) catalogue lists 166 species of Rhyparida, an increase of $34.3 \%$ over the account by Lefèvre (1885), thirty years earlier. Today, there are 361 species recognized as belonging into the genus Rhyparida, which appear predominantly distributed in Australia (110 species) and the main island of New Guinea (99 species). The remaining species are mostly distributed in the Philippines (32 species), Sulawesi (18 species) and many other islands of Indonesia, as well as in several archipelagoes of the Micronesia and Melanesia (Fig. 4). Very few species occur in continental South East Asia. Interestingly, the genus had not been reported so far from New Caledonia, despite all other surrounding archipelagoes having several species, including Fiji with ten recognized taxa (Bryant and Gressitt 1957), and that the genus reaches as far east as Samoa (Gressitt 1957).

It is largely elusive understanding why such a diverse genus like Rhyparida is so rare in New Caledonia, considering the old age of the island, its relatively large size, its ecological diversity and its relative proximity to species-rich source areas such as New Guinea and Australia, as compared to Fiji, for instance, comparatively rich in species of Rhyparida. Island disharmony is a well-known biogeographic pattern, and very common in the case of insects in Pacific islands (see Gillespie and Roderick 2002). Thus, Rhyparida could represent one more example of biased composition of an island community. But perhaps the attention should be on Fiji and a disharmonic excess of Nodinini, not only Rhyparida but several other genera as well, compared to surrounding archipelagoes (Bryant and Gressitt 1957). Fiji supports in turn a comparatively poor Colaspoidini fauna, highly diverse in New Caledonia. In any case, in the absence of a reconstruction for the evolutionary history of this group, whatever explanation we attempt at these patterns remains speculative. Chance determines that island biotas are a non-representative sample of their continental counterparts, and the classical mechanistic justification of differential odds for initial colonization of an island invokes dispersal capabilities of the species in potential sources (Grant 1998). We do not have any reason to believe a priori that Rhyparida is less suited for transoceanic dispersal compared to other eumolpines such as Dematochroma, which have reached, successfully colonized and radiated in New Caledonia. For instance, all New Caledonian eumolpines, including Rhyparida foaensis, are winged, the same as their continental relatives. And of course, the presence of the genus in Samoa argues against inherent limitations to dispersal potential.

If differences in ability for dispersal compared to other eumolpines are not obvious, another possibility is that successfully colonizing Rhyparida (or other Nodinini for that matter) were outcompeted by local stable populations of Colaspoidini, in this 


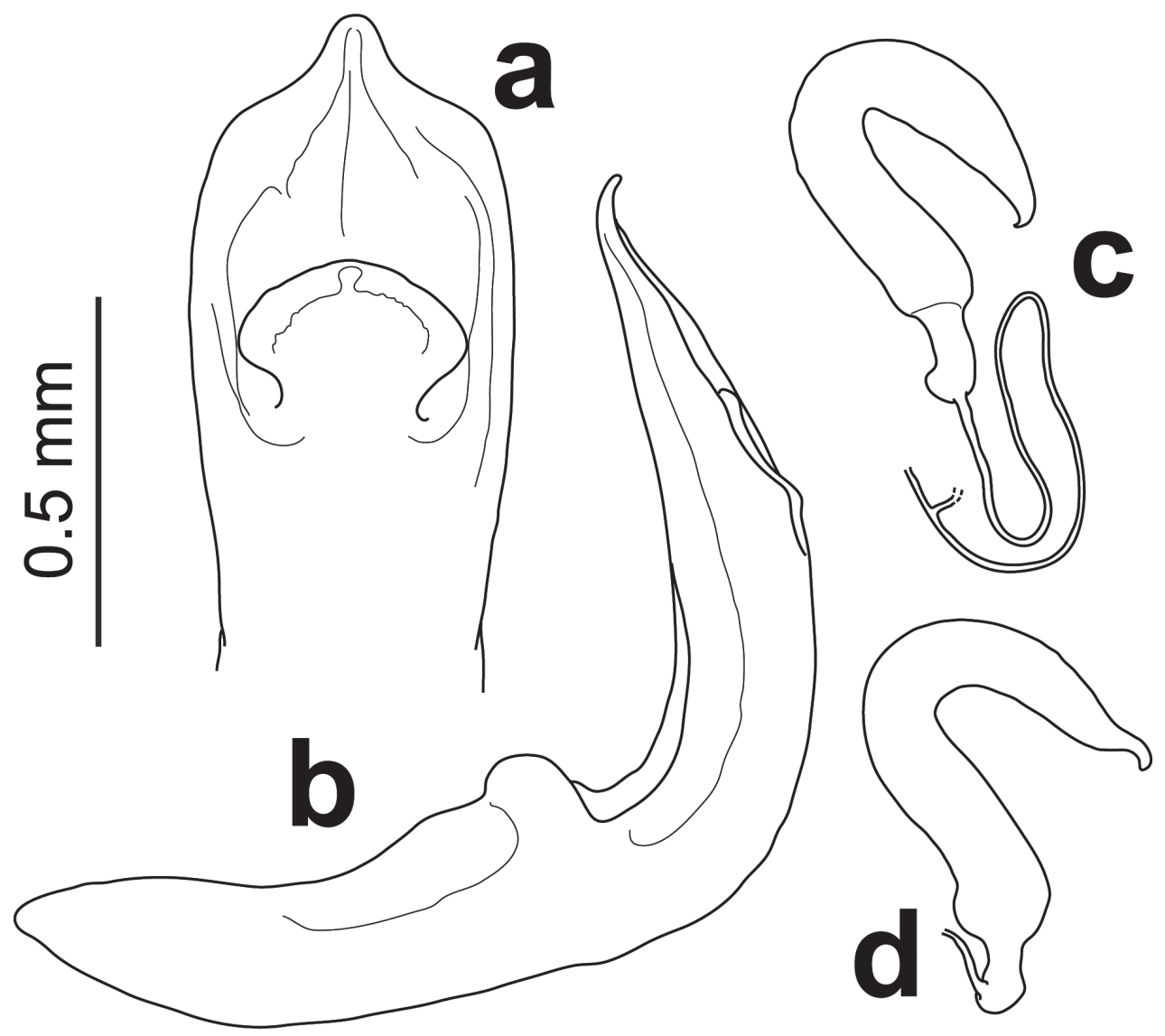

Figure 3. Male (a dorsal b lateral) and female c, d genitalia of Rhyparida foaensis (Jolivet, Verma \& Mille).

case. Again, and considering the generally eclectic ecologies of these animals, their notable success in similar geographic scenarios also rich in other eumolpines, and the diversity of suitable habitats offered by New Caledonian ecosystems, it is difficult to admit that such a fierce antagonism and exclusion can affect settlement chances for representatives of an entire beetle tribe.

Yet another possibility is that ecological requirements for Nodinini, or Rhyparida in particular, are actually stricter than considered a priori, and not available in New Caledonia, compared to the mainland or surrounding oceanic islands. This hypothesis could be evaluated examining for instance the association of Rhyparida species to specific soils, types of vegetation or specific plants throughout its range and confirming the absence (or rarity) of these conditions in New Caledonia, remarkable and quite unique for its geologic and mineral characteristics (Jaffré 1993; Morat 1993). However, perhaps the importance of host plants in this specific case of island disharmony could be neglected, since Rhyparida appears in the literature associated to many different hosts, most of them or their relatives present in New Caledonia. Species of Rhyparida have 


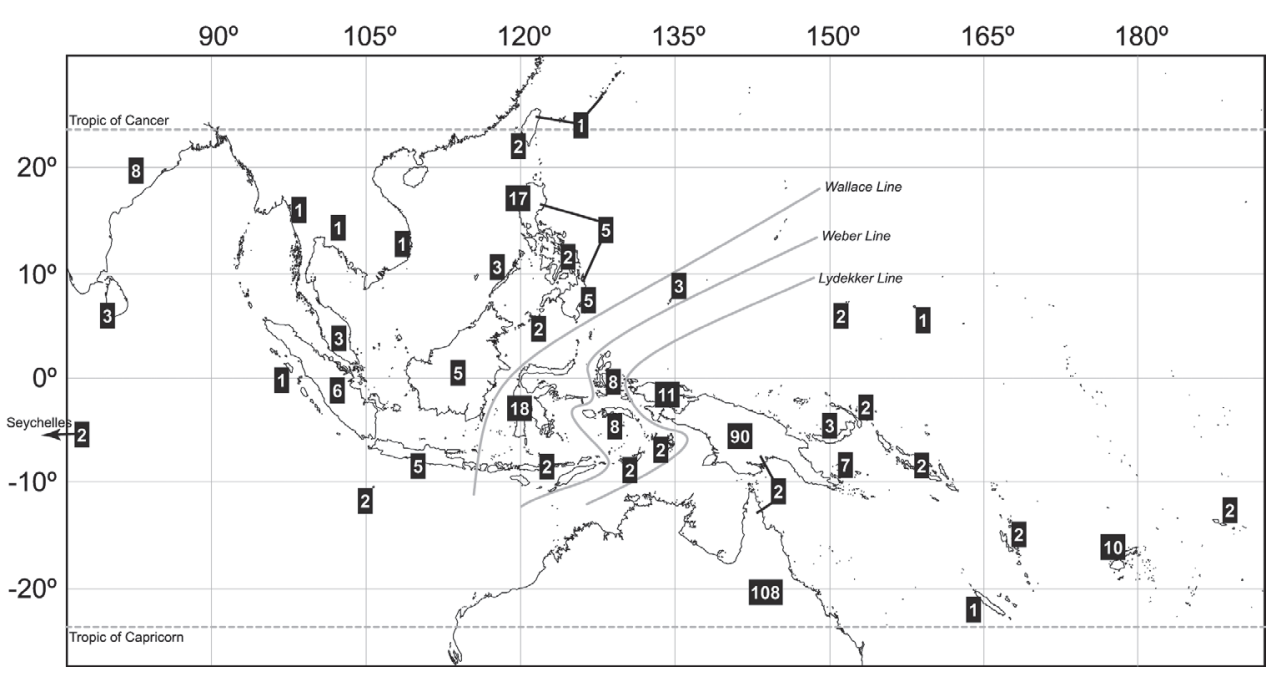

Figure 4. Distribution and diversity of Rhyparida Baly species worldwide.

been reported as feeding on dicot Anacardiaceae (Sapindales), Asteraceae (Asterales), Dilleniaceae (Dilleniales), Loganiaceae (Gentianales), Malvaceae (Malvales), Moraceae (Rosales) and Rhizophoraceae (Malpighiales), and monocot Arecaceae (Arecales), Pandanaceae (Pandanales), and Poaceae (Poales) (Bryant and Gressitt 1957; Chûjô and Kimoto 1961; Gressitt 1955, 1967), with species like $R$. coriacea Jacoby and $R$. carolina Chûjô found and explicitly reported on many hosts (Gressitt 1955, 1967). Indeed, as it occurs with many eumolpines, it is possible that Rhyparida species are polyphagous as root feeding larvae, but also as adults (Jolivet and Verma 2002). If this were the case, they would have a high colonization potential of new habitats, particularly those offering such a diverse range of potential hosts as New Caledonia, but also intermediate islands along their possible colonization routes. The host or hosts of $R$. foaensis are not known, but some of the specimens available for study were collected on the so-called niaouli, a dominant shrub in savannah-like environments in the south of Grande Terre currently included in the genus Melaleuca (Myrtales: Myrtaceae), very diverse in Australia and with a similar range as the genus Rhyparida.

A last possibility about the paucity of Nodinini in New Caledonia and worth consideration here is that there may be several species in the archipelago still awaiting discovery. Considering the intense sampling in the recent past and the conspicuous characters diagnosing this tribe, although it is likely that new species will be discovered, it appears improbable that the catalogue of New Caledonian Nodinini will grow to a number of species comparable to that found in Fiji or even Samoa, the later with at least eight species among Rhyparida, Stethotes and Stygnobia (Gressitt 1957).

The number of questions that this intriguing pattern suggest and the few, speculative answers available, highlight the importance of further research on New Caledonian fauna, from biodiversity and ecological surveys to phylogenetic analyses which 
will help understanding the history of colonization and diversification on this remote biodiversity hotspot.

\section{Replacement names for the genus Rhyparida}

During the course of this study, several homonyms were detected affecting the genus Rhyparida Baly, which need name replacements to avoid ambiguity. Rhyparida leana nom. n. (after Arthur Mills Lea) is proposed as replacement name for the Australian species Rhyparida apicipennis Lea, 1915, name preoccupied by a species from Fergusson Island (Papua New Guinea) described by Jacoby (1898). Both Lea (1915) and Weise (1922) used the name $R$. pallidula to describe species from Australia and the Philippines, respectively; the name Rhyparida weiseana nom. n. (after Julius Weise) is suggested to replace Weise's younger taxon. Finally, Lea (1915) named an Australian species using the same name, $R$. prosternalis, previously proposed by M. Jacoby for a species found in Indonesian Papua (Jacoby 1894); Lea's name is thus replaced here by Rhyparida reiterata nom. nov. (from post-classical Latin reiteratus $=$ repeated).

\section{Acknowledgements}

I express my gratitude to Pierre Jolivet (Museum Nationale d'Histoire Naturelle, Paris), Ottó Merkl (Magyar Természettudományi Múzeum, Budapest), Max Barclay and Beulah Garner (Natural History Museum, London), and Matthias Schöller (Berlin) for kindly allowing me to study the Eumolpinae material discussed here. Anabela Cardoso (Institut de Biologia Evolutiva CSIC-UPF, Barcelona) and José A. Jurado-Rivera (IMEDEA, CSIC-UIB, Palma de Mallorca) collected the specimen of D. laboulbenei (Montrouzier) figured in this work. Pierre Jolivet and an anonymous referee reviewed the original version of the manuscript and helped me improve it. I also want to thank Lyubomir Penev (Bulgarian Academy of Sciences / Pensoft Publishers, Sofia) and Michael Schmitt (Ernst-Moritz-Arndt-Universität, Greifswald) for considering this work a suitable contribution for this special ZooKeys issue on leaf beetle research. This study received the support of a travel grant from the Committee of Research and Exploration (Contract No. 8380-07, National Geographic Society) and from the Percy Sladen Memorial Fund (Linnean Society of London).

\section{References}

Bryant GE, Gressitt JL (1957) Chrysomelidae of Fiji (Coleoptera). Pacific Science 11: 3-91. Chapuis F (1874) Genera des Coléoptères ou exposé méthodique et critique de tous les genres proposés jusqu'ici dans cet ordre d'insectes. Tome X. Famille des Phytophages. Librairie Encyclopédique de Roret, Paris, 455 pp. 
Chûjô M, Kimoto S (1961) Systematic catalog of Japanese Chrysomelidae (Coleoptera). Pacific Insects 3: 117-202.

Clavareau H (1914) Chrysomelidae: 11. Eumolpinae. Pars 59. Coleopterorum Catalogus (S. Schenkling Ed.). W. Junk, Berlin, 215 pp.

Fauvel A (1862) Coléoptères de la Nouvelle-Calédonie, recueillis par M. E. Déplanche, chirurgien de la Marine Impériale, 1858-59-60 (1ère Partie). Notices Entomologiques, A. Hardel, Caen, 68 pp.

Gillespie RG, Roderick GK (2002) Arthropods on islands: Colonization, speciation, and conservation. Annual Review of Entomology 47: 595-632. doi: 10.1146/annurev. ento.47.091201.145244

Gómez-Zurita J (in press) Revision of New Caledonian species of Eumolpinae described by K. M. Heller (Coleoptera: Chrysomelidae). Zootaxa.

Grant PR (1998) Patterns on islands and microevolution. In: Grant PR (Ed) Evolution on Islands. Oxford Univ. Press, Oxford, 1-17.

Gressitt JL (1955) Insects of Micronesia. Coleoptera: Chrysomelidae. Insects of Micronesia 17: $1-60$.

Gressitt JL (1957) Chrysomelidae of Samoa (Coleoptera). Proceedings of the Hawaiian Entomological Society 16: 241-258.

Gressitt JL (1967) Chrysomelid beetles from the Papuan subregion, 4 (Eumolpinae, 2). Pacific Insects 9: 295-340.

Gressitt JL (1969) Chrysomelid beetles from the Papuan subregion, 6 (Eumolpinae, 4). Pacific Insects 11: 1-31.

Heller KM (1916) Die Käfer von Neu-Caledonien und den benachbarten Inselgruppen. In: Sarasin F, Roux J (Eds) Nova Caledonia, Zoologie, Vol. II, L. III. C. W. Kreidels Verlag, Wiesbaden, 229-364.

Jacoby M (1894) Descriptions of new genera and species of phytophagous Coleoptera obtained by W. Doherty in the Malayan archipelago. Novitates Zoologicae 1: 267-330.

Jacoby M (1898) New species of Phytophagous Coleoptera from Australia and the Malayan regions. Annales de la Société entomologique de Belgique 42: 350-380.

Jaffré T (1993) The relationship between ecological diversity and floristic diversity in New Caledonia. Biodiversity Letters 1: 82-87. doi: 10.2307/2999751

Jolivet P, Verma KK (2002) Biology of Leaf Beetles. Intercept, Andover, 332 pp.

Jolivet P, Verma KK, Mille C (2007a) New species of Eumolpinae from the genera Dematochroma Baly, 1864 and Taophila Heller, 1916 from New Caledonia (Coleoptera, Eumolpinae). Revue française d'Entomologie (N.S.) 29: 33-47.

Jolivet P, Verma KK, Mille C (2007b) New genera and species of Eumolpinae from New Caledonia (Coleoptera, Chrysomelidae). Revue française d'Entomologie (N.S.) 29: 77-92.

Jolivet P, Verma KK, Mille C (2008) New species of Dematochroma and Colaspoides from New Caledonia (Coleoptera, Chrysomelidae, Eumolpinae). Nouvelle Revue d'Entomologie (N.S.) 24 [2007]: 195-200.

Jolivet P, Verma KK, Mille C (2010) Eumolpinae recently collected in New Caledonia and Vanuatu (Coleoptera, Chrysomelidae). Nouvelle Revue d'Entomologie (N.S.) 26 [2009]: 3-17. 
Keast A (1996) Pacific biogeography: Patterns and processes. In: Keast A, Miller SE (Eds) The origin and evolution of Pacific island biotas, New Guinea to Eastern Polynesia: patterns and processes. SPB Academic Publishers, Amsterdam, 477-512.

Lea AM (1915) Notes on Australian eumolpides (Coleoptera, Chrysomelidae), with descriptions of new species. Transactions and Proceedings of the Royal Society of South Australia 39: 102-339.

Lefère E (1876) Descriptions d'eumolpides nouveaux ou peu connus. Revue et Magasin de Zoologie Pure et Appliquée (3e Sér.) 4: 278-311.

Lefevre E (1885) Eumolpidarum hucusque cognitarum catalogus, sectionum conspectu systematico, generum sicut et specierum nonullarum novarum descriptionibus adjunctis. F. Hayez, Impr. Acad. Roy. Belgique, Bruxelles, 172 pp.

Montrouzier X (1861) Essai sur la faune entomologiqe de la Nouvelle-Calédonie (Balade) et des îles des Pins, Art, Lifu, etc. Annales de la Société entomologique de France (4ème sér.) 1: 265-306.

Morat P (1993) Our knowledge of the flora of New Caledonia: endemism and diversity in relation to vegetation types and substrates. Biodiversity Letters 1:72-81. doi: 10.2307/2999750

Weise J (1922) Chrysomeliden der Philippinen, III. The Philippine Journal of Science 21: 423-490. 